\title{
An Introduction to the African Commodity Trade Database, 1730-2010
}

\section{Social and Economic History}

\author{
Ewout Frankema \\ Pieter Woltjer \\ Angus Dalrymple-Smith \\ Leandre Bulambo \\ Wageningen University, The Netherlands \\ ewout.frankema@wur.nl \\ p.j.woltjer@rug.nl \\ angus.dalrypmple-smith@wur.nl \\ leandre.bulambo@wur.nl
}

\begin{abstract}
The African Commodity Trade Database (ACTD) aims to stimulate and deepen research on African and global economic history. The database provides export and import series at product level for more than two and a half centuries of African trade (1730-2010). This article introduces potential users to some of the major questions that can be explored with African commodity trade data, as well as the sources, structure and limitations of the dataset. The current version of the ACTD is downloadable from the data repository of the African Economic History Network (www.aehnetwork.org/ data-research) and will be regularly updated with new data.
\end{abstract}

\section{Keywords}

African history - international trade - economic history

- $\quad$ Related data set "African Commodity Trade Database" with uRL https:// doi.org/10.17026/dans-xt9-fzkw in repository "DANs".

- See the showcase of the data in the Exhibit of Datasets: http://dansdatajournal.nl/rdp/dsdoc.html?id=frankema2018

(C) EWOUT FRANKEMA, PIETER WOLTJER, ANGUS DALRYMPLE-SMith \& LEANDRE BULAMBO, 2018 | DOI:10.1163/24523666-01000009 | This is an open access article distributed under the terms of the prevailing $\mathrm{CC}-\mathrm{BY}$ license at the time of publication. 
1. Introduction

Long-term patterns of international trade between states and world regions form the core of historical processes of economic globalization and de-globalization, and constitute one of the major themes in economic history (Wallerstein 1974, O'Rourke \& Williamson 1999, Williamson 2011). With the important exception of its role in the trans-Atlantic slave trade (Eltis et al. 1999, Klein 2010) Africa has featured poorly in historical accounts of world trade. There are several reasons for this lack of attention. First, even when including the trade in slaves, African shares in total world trade have been rather small in the past five centuries. Second, African commodity trade has not been recorded in similar detail as in most other regions of the world. Third, the documentation that has survived tends to be biased because most of it has been compiled by foreigners, such as European merchants or colonial tax officials, and often in entry/exit ports of Europe and the Americas, instead of Africa.

Even though African countries or regions are incorporated in large global datasets of international trade (e.g. Fouquin and Hugot 2016) or in older 'preExcel' databases (e.g. Johnson et al. 1990), the available data has never been fully gathered nor fully exploited. On the contrary, large parts of the available sources have remained unused despite their potential to cast new light on Africa's long-term involvement in the globalization process. The ACTD aims to fill this gap. ${ }^{1}$ The main reason that historical trade records exist is that crossborder trade offers an easy source of taxation. Especially with sea-bound trade, all a state has to do is establish a tax office in the main harbours, one of the first things that colonial regimes in Africa would organize in order to raise funds for their state-building projects (Frankema 2011, Frankema and van Waijenburg 2014)..$^{2}$ This also implies that another part of African trade with the rest of the world has been recorded in European, Asian or American ports of entry and exit. Despite large gaps, the ACTD represents the largest effort to date to collect and present African commodity trade in order to investigate long-term trends in volumes, prices, terms of trade and product composition of exports and imports. We briefly introduce a variety of themes the ACTD can speak to.

1 The African Commodity Trade Database (ACTD) has been created as part of the ERC project Is Poverty Destiny? A New Empirical Foundation for Long-Term African Welfare Analysis, conducted at the Rural \& Environmental History group of Wageningen University (2012-2017). We gratefully acknowledge funding by the European Research Council for this project (ERC Grant Agreement no. 313114).

2 Note that African states also used to tax trade, but that much of it remained unrecorded, or has been recorded but did not survive the test of time (see for instance Law 1978). 


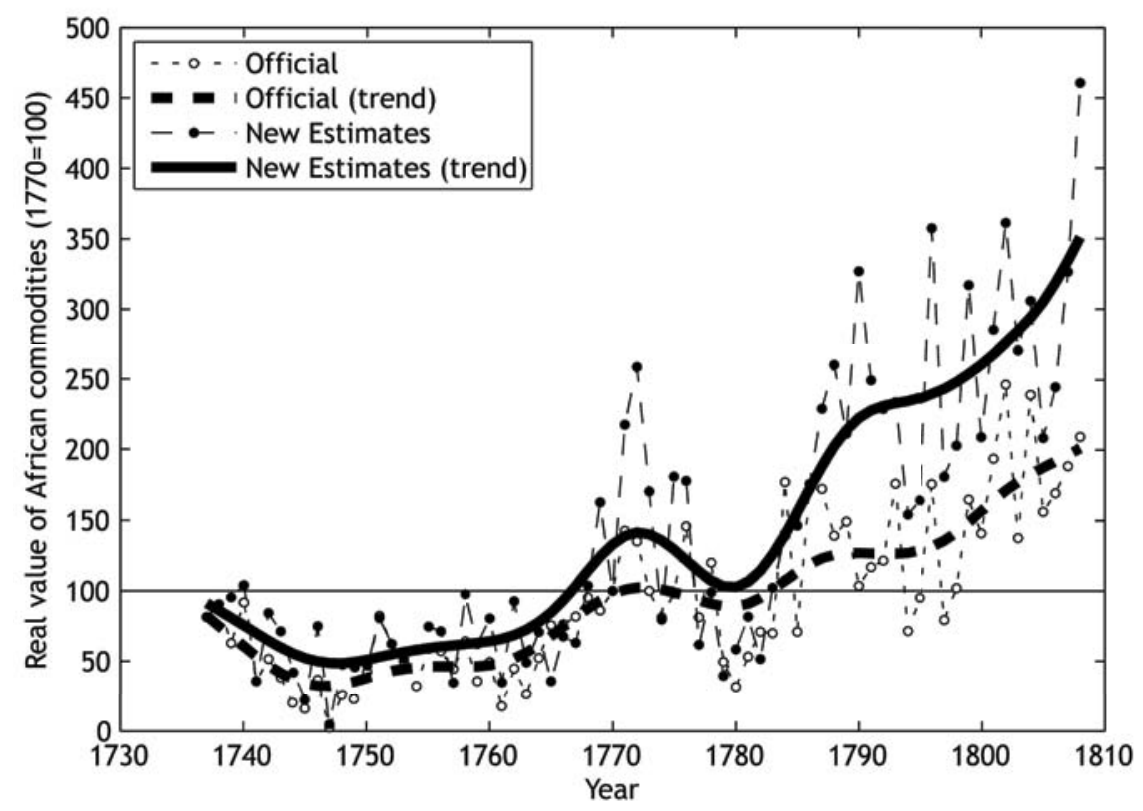

FIGURE 1 Real value of African commodity imports, 1737-1808 (1770=100). Trend derived using Hodrick-Prescott filter, with a smoothing factor set to 100.

DALRYMPLE-SMITH AND WOLTJER (2016).

First, the gradual intensification of African trade with the rest of the world, which fills major gaps in our understanding of the continent's economic history (see for a survey of such gaps Manning 2012). Comparisons of commodity exports and imports to the slave trade data contained in the Trans-Atlantic Slave Trade Database (Eltis et al. 1999) offers a more comprehensive understanding of the nature of African trade in the wider Atlantic world. The ACTD provides a major improvement on previous work by Johnson et al. (1990) on the British customs records from the $18^{\text {th }}$ Century. Dalrymple-Smith and Woltjer (2016) have shown that the volume and value of African commodities bought by British traders grew substantially faster than previously estimated (see figure 1) and that the growth of the 'legitimate' commerce even outpaced the growth of the slave trade during the second half of the $18^{\text {th }}$ century. They also found that the regional production of exports such as gold, gum, ivory and palm oil changed over time. For the $19^{\text {th }}$ century, the combination of slave and commodity trade data can be used to explore the variegated dynamics of the so-called 'commercial transition' (the move from exporting slaves to commodities, see Law 1995, Law et al. 2013), which is the main topic of a thesis compiled by DalrympleSmith (2017). 
Important shifts in the composition of exports, and related patterns of economic specialization can also be observed in the long $20^{\text {th }}$ Century. After the discovery of diamonds (1867) and gold (1884) in South Africa, an increasing number of African colonies became dependent on the export of minerals such as copper (Zambia, Belgian Congo) and, mostly after independence, oil (Nigeria, Angola, Sudan, Niger, Equatorial Guinee). Contemporary trade data also reveals that a further diversification of exports away from primary commodities towards (light) manufactures has not (yet) taken place. A major part of the post-1990 economic boom in Africa has been based on sharply rising export revenues. This boom was partly driven by favourable world market price developments, but has recently come to an end (Austin et al. 2017).

Second, the development of relative prices, or what economists call 'net barter terms of trade'. Long-term index series of export and import prices aid the interpretation of area-specific paths of export specialization. Were these paths beneficial or detrimental for the purchasing power of African exporters? Since the ACTD contains both quantities and unit prices of traded commodities, the dataset can be used to assess the development of African trade in comparison with other commodity exporting regions using identical methods of estimation (Williamson 2011). Terms of trade series derived from the ACTD, also make it possible to study the intra-African variation in commodity price

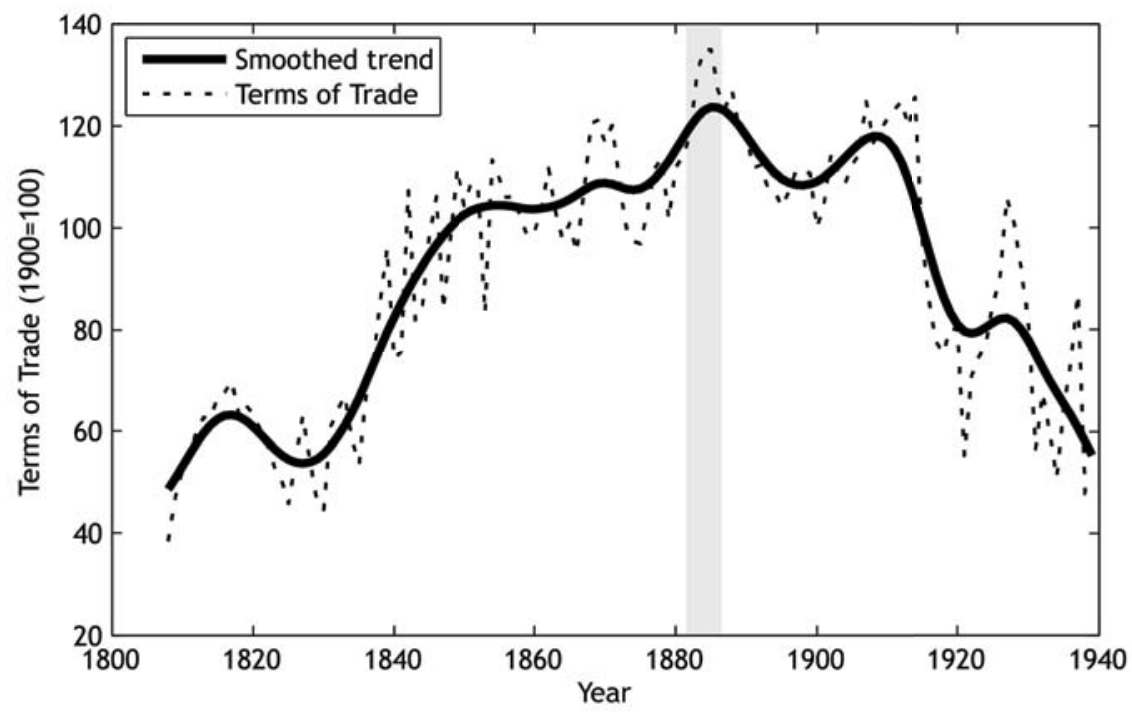

FIGURE 2 Terms of trade for West Africa, 1808-1939 (1900=100). Smoothed trend derived using Hodrick-Prescott filter, with a smoothing factor set to 100.

FRANKEMA ET AL. (2018). 
developments. Revisiting older work by Hopkins (1973) and Eltis and Jennings (1988), Frankema, Williamson and Woltjer (2018) have found a prolonged rise in the net barter terms of trade for sub-Saharan Africa from the 1800 s to the 188os. Figure 2 shows that this secular price boom peaked around the date of the Berlin conference for West Africa (1884-5), which fastened the European partition of Africa. While the terms of trade for commodity exporters were rising in most of the non-Western world, the African boom was larger than elsewhere. After the Berlin conference, however, the relative prices of major African export products started a prolonged descent. This price bust continued, with only some temporary reversals, up to the eve of World War II. In 1940, Africa's terms of trade were back at their 1800 levels. The large volatility of international primary commodity prices has been identified as one of the major causes of economic instability, and especially in countries with dysfunctional political systems (Deaton 1999).

The ACTD also allows for a comparison of the relative shares of the major colonial powers, i.e. Britain and France, in African international trade up to 1960. Table 1 below shows that African export volumes continued to expand after 1885 at a faster pace than before, thus offsetting the relative price declines. Hence, African farmers, European planters and mining firms specialised in commodities that became worth less and less. Yet, there were distinctive differences, as Table 1 shows, in the magnitude of this perverse trend of specialization between French and British territories. In French Africa, the terms of trade fell more dramatically, but export volume rose dramatically faster in British West Africa after 1885 .

Third, the impact of changing factor proportions and (colonial) economic policies on long-term economic development. The ACTD can help economic historians to build and extend explanatory models of trade specialization and to measure market integration, either between African countries or, when combined with other trade databases, between the (former) colonizers and colonies. With complementary data on labour, land and capital supplies, as well as import and export tariffs and internal transportation costs (which are not in the dataset, but are in the process of being assembled for specific regions in Africa), larger questions can be addressed: were African economies hampered by perverse specialization because of adverse (colonial) institutions, or by factor proportions dictating long-term specialization in land-intensive and labour-extensive primary commodities? Did tariff policies have any effect on shifting patterns of trade, for instance during the period of Import substitution industrialization (Austin et al. 2017)? The import statistics can also be used to shed light on Africa's stymied industrialization progress. To what extent can the continued reliance on imported capital equipment and intermediate 
(1)

$\begin{array}{lll}\begin{array}{l}\text { Purchasing } \\ \text { power of } \\ \text { export }\end{array} & \begin{array}{l}\text { Import } \\ \text { price }\end{array} & \begin{array}{l}\text { Export } \\ \text { price }\end{array} \\ & & \end{array}$

(4)

Export

volume
(5)

Price

Volume

British West Africa $(£)$

\begin{tabular}{|c|c|c|c|c|c|c|}
\hline $1853^{-1885}$ & 4.65 & -0.68 & 0.83 & 3.14 & 32 & 68 \\
\hline $1885^{-1929}$ & $5 \cdot 49$ & 1.32 & 0.46 & 6.36 & -16 & 116 \\
\hline \multicolumn{7}{|c|}{ French West Africa (Fr.) } \\
\hline $1853-1885$ & 4.96 & -1.06 & 1.67 & 2.23 & 55 & \\
\hline $1885^{-1929}$ & 1.98 & 4.43 & $3 \cdot 3^{8}$ & 3.03 & -53 & 15 \\
\hline
\end{tabular}

Note: growth rate in natural logs. The purchasing power of export in column (1) is the sum of columns (3) and (4) minus (2). The price contribution is the difference between columns (3) and (2) divided by (1). The volume contribution is the ratio of (4) and (1). May not sum to total due to rounding. SOURCE: FRANKEMA ET AL. (2018).

manufacturing inputs explain late or absent industrialization? In an age where Africa's role in the world economy is bound to change, if only because of its booming population, more research on such long-term patterns of trade specialization are crucial.

Fourth, the rising share of mineral exports in African trade has given rise to a significant economic debate on the effects of the resource curse (van der Ploeg 2011). The ACTD can be used to trace the historical evolution of the proportion of mining produce in African exports. Such specialisation patterns are also important on the import side, and especially with regard to the transition of net food imports, which is another feature of $20^{\text {th }}$ century trade in the region. And finally, fifth, trade data play a role in studies of economic and political development as explanatory variable or as a factor in the construction of macroeconomic indicators. For instance, in the growing literature on (colonial) African fiscal history, the opportunities and constraints to the collection of custom duties and related trade taxes are a key factor (Frankema 2011, Gardner 2012, Frankema and van Waijenburg 2014), and for the construction of national income estimates international trade data are crucial as well (Prados de la Escosura 2012). 


\section{The Dataset: Sources, Structure and Limitations}

- African Commodity Trade Database, deposited at DANS - Dor:https://doi. org/10.17026/dans-xtg-fzkw

- Temporal coverage: $1730-2010$

The ACTD consists of three main parts which will be continuously updated as we retrieve additional sources. This split in three parts is primarily motivated by the type of sources that are available and the different territorial specification of the exports and imports reported in the sources. For example, for the colonial era (c. 1880-1960) trade has been recorded for distinct colonies, but for the pre-colonial era we obtained references to a specific port (e.g. Lagos) or, a specific coastal region (e.g. Senegalese coast). Up to c. 1830 the data is primarily derived from British, Dutch and French sources recording imports from Africa into their home countries. After 1830 an increasing part of the records contain observations of imports and exports at the African coast, regardless of their final destination. Territorial designations eventually became more specific with the rise of colonial and post-colonial states. During the colonial era, territorial borders were defined more precisely, and railway construction played a crucial role in the connection of specific economic enclaves in the African interior that were producing for global markets.

The biggest weakness of the dataset that will never be resolved, is that up to ca. 1945, intra-African trade is excluded from the dataset. This is for the simple reason that the bulk of it has never been recorded as it was either unobserved, or did not cross a formal 'national border' in the way we currently would define one. Hence, the trade data for the period 1730-1940 exclusively covers seabound trade. For the post-1940 era trade between African countries has been included. Interestingly, the volumes and values of intra-African trade have long remained a small share of the total, but with fast growing urban consumer markets this is now changing.

\section{3.} $1730-1808$

The primary sources for the eighteenth- and early nineteenth-century commodity trade are the British customs records. These records contain detailed, annual data on the quantity of African commodities exported to Britain as well as British goods imported into Africa. The customs records lack any price data, however, except for the official prices recorded in 1697 which, as argued by Dalrymple-Smith and Woltjer (2016), have lead Johnson et al. (1990) to greatly 
underestimate the development of 'legitimate' commerce in the second half of the eighteenth century. We supplemented the quantity data in the customs records with data on prices for primarily West African commodities from a variety of British and Dutch merchant and government sources. To match the price and quantity data we standardised the weights and measures given in the sources, converting all prices into British Pounds and all weights into either pounds or gallons. The ACTD presents new price series for the main African exports and imports as well as detailed quantity data at the product level, but we also re-estimated series of the nominal and real values of total West-African trade. For the latter, we rely on continuously changing (price) weights to aggregate the different commodities into a single quantity index. This allows us to overcome the index number problems plaguing the official quantity index, resulting from the use of fixed and often unrepresentative prices set by the British customs office.

The main limitations of this part of the ACTD are threefold. First, the data focus primarily on commodity trade with West Africa. Excluding South Africa, West Africa featured most prominently in the sub-Saharan commodity trade and arguably presents the most interesting case for future study. Second, the quantity data is based exclusively on British sources, it thus omits any trade carried out by other (European) trading partners. It should be noted, however, that, except for the Senegambian region, the commodity trade was overwhelmingly dominated by British vessels (Eltis 2013). Third, the price data does not cover the full range of products for which we have quantity information. However, the ACTD does contain data for the key commodities and goods traded with Africa including amongst others beeswax, gum, ivory, pepper, palm oil, redwood, alcohol, cotton, gunpowder, iron, tobacco, Indian textiles and cowries.

4.

1808-1939

This part of the ACTD primarily presents the annual price and quantity data listed in the British Statistical Abstract for the Several British Colonies, Possessions, and Protectorates, the African Blue Books and the French Tableau General du Commerce de la France avec ses Colonies et les Puissance Etrangeres. We merged the data from these primary trade accounts with several existing series to produce annual time-series of export and import volumes, values, and prices as well as a NBTT series. The data cover over fifty products including foodstuffs, cash-crops, forest products, metal ores, and minerals. For 1808 1829 the data is different than for the post-1830 era. For $1808-1829$ most of the observations are drawn from British trade with West and South Africa listed in 
the handwritten British Customs Records. French trade with West Africa were taken from French import statistics. For the African islands the pre-183o series focus on sugar, which covered over 80 percent of the islands' export value, and for the East African coast the data up to 1890 are based on ivory exports derived from the work of Sheriff.

For the post-1830 era the ACTD covers exports and imports of nineteen areas in Sub-Saharan Africa for which we collected price information at the African coast. We constructed export price indices using annual prices quoted at African ports for 1830-1939 and extrapolated these indices backwards to 1808 using American wholesale prices, converted into British pounds using official exchange rates. We corrected these wholesale prices for trade costs (e.g. international transport costs, insurance and retail margins). Where several commodity prices were available from different areas, we weighted each by its volume share in total African exports. French prices were converted to British pounds using quoted exchange rates. Where African price data were missing for the 1830-1939 period, we interpolated the commodity price indices based on the British wholesale prices trends.

Within the limitations of the available historical sources, our dataset has a larger spatial and temporal coverage and includes much more product detail than previous databases. In the 'pre-spreadsheet era' it was complicated to connect trade series from a variety of sources and apply fine-grained extrapolation techniques (Forbes-Munro 1976; Hanson 1980; Liesegang et al. 1986; Eltis and Jennings 1988). Moreover, none of these studies engaged in comparisons with other parts of the 'poor' commodity-exporting world, because comparable studies on Asia and Latin America also emerged later, in the 1990s and 2000s (O'Rourke and Williamson 1999; Williamson 2011). More recent work on African terms of trade has either focused on a single commodity, or looked into post-1870 trade developments, including terms-of-trade analyses, but for different analytical purposes (Deaton 1999; Allen 2011).

\section{5. $\quad 1945-$ Present}

The third part of the ACTD, covering the post-war era, is currently under construction. In some respects, it will be more complete, and in other respects it will be far less complete than the second part of the dataset. The data are mainly retrieved from the UN International Trade Statistics, which presents data from statistical agencies of late colonial and national African governments. The UN trade statistics have adopted the Standard International Trade Classification (SITC) to organize exports and imports into ten main product categories: o) 
Food \& animals, 1) Beverages \& tobacco, 2) Crude materials, 3) Mineral fuels, 4) Animal \& vegetable oils and fat, 5) Chemicals, 6) Basic manufactures, 7) Machinery \& transport equipment, 8) Manufactures, miscellaneous and, 9) Goods unclassified. This categorisation makes it easier to distinguish trends in export specialisation and changing patterns of imports. However, large gaps in the coverage emerge during the 1970s-1990s, when many African countries experienced a combined economic and political crisis, and the practices and capacities of statistical surveillance rapidly deteriorated.

As a rule of thumb we only include commodities exceeding 5 percent of export or import value. Since African exports remained rather undiversified throughout this period, these generally consist of only a handful of 'main' commodities. Imports were more diversified. The dataset includes all 55 African states and takes border changes in the period into account. We are elaborating the UN trade data by calculating price indices and net barter terms of trade, using international world market price series for major primary commodities such as cotton, coffee, cocoa, copper, gold and oil.

\section{Future Extensions}

The construction of the ACTD is an on-going project and will probably never be entirely finished. Its data can be used by researchers to consider a wide range of issues concerning long-term African economic development and sheds light on Africa's changing role in the globalization process. At present, the two main priorities are 1) to complete a first version of the post-1945 dataset and 2) to extend the spatial coverage of the trade data for the colonial era, especially by incorporating Portuguese, Belgian and German Africa. This effort will help address the current bias of the data towards African trade with Britain and France. It will also allow us to construct time-series running up to the present. In the more distant future we plan to add data on trade tariffs, offer a more detailed decomposition of imports and add more price observations for the pre-abolition era.

\section{References}

Austin, G., Frankema, E., \& Jerven, M. (2017). "Patterns of Manufacturing Growth in Sub-Saharan Africa: From Colonization to the Present". In K. O'Rourke \& J. G. Williamson (Eds.), The Spread of Modern Industry to the Periphery since 1871. Oxford: Oxford University Press, pp. 345-373. 
Allen, R. C. (2011). Global Economic History: A Very Short Introduction. Oxford: Oxford University Press.

Dalrymple-Smith, A. (2017). A comparative history of commercial transition in three West African slave trading economies, 1630 to 1860 . PhD-thesis, Wageningen University.

Dalrymple-Smith, A., \& Frankema, E. (2017). Slave Ship Provisioning in the Long 18th Century: A Boost to West African Commercial Agriculture? European Review of Economic History 21(2), 185-235.

Dalrymple-Smith, A., \& Woltjer, P. (2016). Commodities, Prices, and Risk: The Changing Market for Non-Slave Products in Pre-Abolition West Africa, African Economic History Network Working Paper No. 2016/31.

Deaton, A. (1999). Commodity prices and growth in Africa. Journal of Economic Perspectives, 13(3), 23-40.

Eltis, D., Behrendt, S. D., Richardson, D., \& Klein, H. S. (1999). The trans-Atlantic slave trade : a database on CD-ROM. Cambridge, UK: Cambridge University Press.

Eltis, D. (2013). "The Slave Trade and Commercial Agriculture in an African Context." In Commercial agriculture, the slave trade and slavery in Atlantic Africa, edited by Suzanne Schwarz, Robin Law and Silke Strickrodt. Boydell \& Brewer Ltd., pp. 28-53.

Eltis, D., and L. C Jennings, (1988). Trade between Western Africa and the Atlantic world in the pre-colonial era. The American Historical Review 93(4): 936-959.

Eltis, D. (2013). The Slave Trade and Commercial Agriculture in an African Context. In S. Schwarz, R. Law \& S. Strickrodt (Eds.), Commercial Agriculture, the Slave Trade and Slavery in Atlantic Africa: Boydell \& Brewer Ltd.

Forbes-Munro, J. (1976). Africa and the international economy, 1800-1960: an introduction to the modern economic history of Africa south of the Sahara. Worthing: Littlehampton Book Services.

Fouquin, M., and J. Hugot, (2016). Back to the future. International trade costs and the two globalizations. CEPII Working Paper No. 2016-13. Centre d'etudes prospectives et d'informations internationals, Paris.

Frankema, E. (2011). Colonial Taxation and Government Spending in British Africa, 1880-1940: Maximizing Revenue or Minimizing Effort? Explorations in Economic History, 48(1), 136-149.

Frankema, E., \& van Waijenburg, M. (2014). Metropolitan Blueprints of Colonial Taxation? Lessons from Fiscal Capacity Building in British and French Africa, c. 18801940. Journal of African History, 55(3), 371-400.

Frankema, E., Williamson, J. G., \& Woltjer, P. (2018). An economic rationale for the West African scramble? The commercial transition and the commodity price boom of 1835-1885. The Journal of Economic History, 78(1), 231-267.

Hanson, J. R. (1980). Trade in Transition: Exports from the Third World, 1840-19oo. New York: Academic Press.

Hopkins, A. G. (1973). An Economic History of West Africa. London: Longman. 
Johnson, M., J. T. Lindblad, and R. Ross, (1990). Anglo-African trade in the eighteenth century: English statistics on African trade 1699-1808. Published by the Centre for the History of European Expansion.

Klein, H. S. (2010). The Atlantic slave trade (New ed.). Cambridge, U.K.; New York: Cambridge University Press.

Law, R. (1978). Slaves, Trade and Taxes: The Material Basis of Political Power in precolonial West Africa. Research in Economic Anthropology, 1(37-52).

Liesegang, G., H. Pasch, and A. Jones, eds. (1986). Figuring African Trade. Berlin: Dietrich Reimer Verlag.

Manning, P. (2012). Historical datasets on Africa and the African Atlantic. Journal of Comparative Economics 40 (4):604-607.

O'Rourke, K., \& Williamson, J. G. (1999). Globalization and History. The Evolution of a Nineteenth-Century Atlantic Economy. Cambridge ma: The mit Press.

Prados de La Escosura, L. (2012). "Output per head in pre-independence Africa: quantitative conjectures." Economic History of Developing Regions 27(2), 1-36.

Van der Ploeg, F. (2011). “Natural Resources: Curse or Blessing?" Journal of Economic Literature 49 (2):366-420.

Wallerstein, I. (1974). The modern world-system. New York: Academic Press.

Williamson, J. G. (2011). Trade and poverty when the Third World fell behind. Cambridge, Mass.: MIT Press. 